\title{
Language Attitude of Sellers in Traditional Market Toward Karonese Language
}

\author{
Siti Aisyah Ginting ${ }^{1}$ \\ ${ }^{1}$ Faculty of Art and Language, State University of Medan, Indonesia \\ Correspondence: Siti Aisyah Ginting, Faculty of Art and Language, State University of Medan, Indonesia. \\ E-mail: aisyah_ginting@yahoo.co.id
}

Received: May 1, 2018 Accepted: June 17, 2018 Online Published: June 19, 2018

doi: 10.5539/elt.v11n7p125 URL: http://doi.org/10.5539/elt.v11n7p125

\begin{abstract}
The purpose of this study was to find out the trades attitude towards the karonese language in Indonesia. Therefore, descriptive analysis research was conducted to get the relevan findings in this study. The data were collected by using interview and documentation techniques. Furthermore, the data were analyzed qualitatively on language attitude. The Finding of this study was there were 12 traders consists of 10 male traders and 2 female traders $(67 \%)$ of respondents showed positive attitudes towards Karonese Language. They said that they are responsible to use Karonese Language since it is their personal identity. In addition, There was nobody using Karonese Language unless themselves. While the researcher found 6 female traders $(33 \%)$ of respondents showed negative attitudes since they usually use Indonesian Language in their daily life activities because their husbands are not Karonese. In conclusion, all male gave positive attitude towards karonese language in traditional market in Indonesia and some females give negative attitude towards karonese language in traditional market in Indonesia.
\end{abstract}

Keywords: language attitudes, karonese language, language identity and culture

\section{Introduction}

The sustainability of a language is largely determined by the language attitude of the speakers of the language itself without any exception whether the language belongs to a national language or as a vernacular language. If the language speakers have a positive attitude towards the language, then the language maintenance will occur, but if the negative language attitude is appeared towards the language, there is a possibility of the language speaker's desire to not maintain the language. The positive and negative language attitudes can be represented from the language speakers' behavior and their customs towards the language itself (Suge, 1967). The language loyalty can be defined as an effort to maintain a certain language, while, language pride is defined as a language speaker's effort to expand their language and use the language as a symbol of an identity and the unity. Furthermore, the awareness of the norm is defined as an attempt to use language carefully and politely (Garvin \& Matthiot, 1968).

In contrast, the negative attitudes toward language can probably occur either intentionally or unintentionally. For instance, the language speakers do not feel proud of the language they have and preferring to use another language which is not their vernacular language. For example, Karonese students who study in college in Medan prefer to use Indonesian language among their friends Karonese-speakers. They do not feel that it is good about using Karo language with Karonese's fellow-speakers. It is because they think that communicating with Karo language is assumed as an out of date or ancient. In addition, they are also lack of understanding about Karo language itself as a language owned by themselves (Surbakti, 2017).

Likewise with Java language, Javanese-adolescents speakers are no longer enthusiastic about using Java language for various reasons appeared. They assume that Java language is not flexible to be used, poorly to be understood, and too complicated because there are many vocabularies which are not easy to be understood. This clearly shows a less positive attitude towards Java language and it can ultimately become negative attitude towards that language. In another case of the adolescents of Aceh tribe, they feel proud to use Aceh language. It can be seen from their behavior when meeting with fellow speakers of Acehnese, they directly use Aceh language when they are talking to each other. The reason given from that attitude is quite good enough, that is because they are proud to use Aceh language. Furthermore, they feel like they are in their own hometown when 
using Aceh language.

If Karonese students who are studying in Medan do not feel good to communicate by using Karo language with their fellow speakers of Karo language, it is contrast with the reality that the women traders in Simalingkar traditional market in Padang Bulan. The women traders always use Karo language when they are communicating to the buyers and to their fellow traders. But, if the buyers do not understand Karo language, they will use Indonesian language. The reason given is very simple, but it has a positive impact on the existence of Karo language. One of that is, they feel happy and they are accustomed using Karo language in their daily life activities. Therefore, this study reveals how the language attitude of the traders in Simalingkar traditional market towards Karo language.

\section{Literature Review}

\subsection{Attitude}

In its simplest definition, attitude refers to reaction towards an object that can be favorable, unfavorable, or in between. Baker (2001) states that attitude is considered as mentality phenomenon which cannot be examined and observed directly but it is manifested in the form of action. In line with the statement, Fishbein and Ajzen (1975) state that attitude can be described as a learned predisposition to respond in a consistenly favorable and unfavorable manner with respect to a given object. Based on the description above, attitude can be concluded as something which is learned towards an object in the early childhood through the process of socialization. In other words, attitudes cannot be observed directly but are demonstrated through actual behavior - for example, how an individual stands on his/her beliefs of an object, how an individual experiences a certain attitude of an object, how an individual behave towards an object, how an individual reacts towards their own language or the other language, and etc. So, attitude can represent internal thoughts, feelings and tendencies in behavior across a variety of contexts.

\subsection{Attitude Towards Language}

Although attitudes cannot be observed directly and must be demonstrated through the actual behavior, but the attitudes towards language can be observed from the way of the language users in talking, in communicating, and in using the language itself. It means that, language cannot be separated from the attitude because language attitudes usually entail attitudes to the speakers of a particular language or dialect (Fasold, 1984).

Based on the above description, it can be assumed that attitudes toward language can be formulated as the evaluation of language in postive and negative way. So that, the people's attitudes toward language who tend to use it will be based on several factors: (1) people believe that particular language has a benefit to them; (2) people tend to feel like to accept the variety of language, they will use it; (3) people's belief and feeling towards a particular language will make them react action to learn the language and use the language itself.

From the three components of attitudes toward the language above which are commonly affect each other, Crystal (2000) states that different communities have different kinds of attitudes and aspirations in relation to their language. It explains that peoples have different attitude with others that called as positive and negative attitude towards the language.

\subsection{Language Attitudes and Its Characteristics}

In conducting the communication, every time the language users use or speak up a certain language, they are not only exchanging information with their interlocutors, but they are also constantly organizing and reorganizing a sense of who they are and how they related to the social world because language also contains the speaker's culture including moral and ethical values (Norton, 2000). According to Crystal (2000), different communities have different kinds of attitudes and aspirations in relation to their language. Those different attitudes performed by people towards their own language or with the other language are called as positive and negative attitude towards the language.

A survey of attitudes toward language can shed light on community beliefs, preferences and desires. The people's attitudes toward the language while interacting with language changes can be seen in form of restoration, preservation, decay or death. The status, value and importance of language can be measured by looking at attitude toward the language. Attitude can be used to explain the direction and persistence of human behavior (Baker, 1992).

Garvin and Mathiot (1968) formulate the following three characteristics of positive language attitude, namely: (1) language loyalty, (2) language pride, (3) awareness of the norms, and negative language attitude, namely: (1) Language disloyalty, (2) Language lack of pride, (3) Unawareness of the norms. These three features of language 
attitude relate to the basis of people in choosing a language form variety of languages that will be used for communication.

\subsubsection{Positive Language Attitude}

Garvin and Mathiot (1968) states that positive language attitude is to use or to treat the language positively in daily interaction. A positive language attitude is an eagerness of the community to use language in all aspects of life. Holmes (2001) states that the positive attitudes support efforts to use the language in variety of domains, and this help people resist the pressure from majority group to switch to their language. The positive language attitudes can be seen when people: (1) feel proud to use the language that they have; (2) are loyal to use it in all domains; (3) have eagerness to maintain the language although there is the situation that forcing them to leave their language and still they are not influenced by anything. In conclusion, the positive language attitudes are really crucial in maintaining a certain language used by a certain community.

\subsubsection{Language Loyalty}

Language loyalty is an attitude that encourages the speaker of a certain language to maintain their language viability from the adverse impact of foreign languages and if it is needed, prohibit the effect of other language influence the existences of their own language. The speaker's loyalty in using and maintaining their own language indicates the positive attitude of the speakers.

\subsubsection{Language Pride}

Language pride is an attitude that encourages a person or a group of people to make the language as a symbol of personal identity or as their group identity where the people of a certain language encourage themselves to spread and use the language as a symbol of identity and symbol of unity. The pride of the speakers to use their language indicates the positive attitudes of the speaker.

\subsubsection{Awareness of the Norm}

Awareness of the norms is an attitude that encourages the use of language carefully, corrective, polite, and decent by the speakers. It encourages the language speaker to use the language in accordance with the applicable norms where the people of a certain language encourage themselves to use the language and accurately. The language awareness is reflected in the responsibility, attitude, and feeling of having a language that raises the willingness to foster and develop the language. Awareness of the norm is an important factor in determining the use of language.

\subsubsection{Negative Language Atitude}

Negative language attitude indicates that a certain community does not support the efforts to use a certain language in their domains. Garvin and Mathiot (1968) state that negative language attitude is unwillingness of the community to use language in all domains. It is believed that negative language attitude categories do not support the language to be maintained. Baker (2001) states that if the language user has negative attitudes towards the language they will have these characteristics; language is seen as an unimportant symbol, language users see an important reason for using the second language, language users see no reason to take active steps to maintain their ethnic language and people are anxious to get on society where knowledge of second language is a prerequisite for success and the effect of these the language will shift. Negative language attitudes are divided into three characteristics, namely (1) Language disloyalty, (2) Language lack of pride, (3) Unawareness of the norm.

\subsubsection{Language Disloyalty}

Language disloyalty is where the people of certain language do not encourage themselves to maintain own language and do not prohibit the effect of other language influence their own language if it is needed. It may indicate that people who do not have the language loyalty are easily influenced by negative factors that force them to leave their language and supposed to use another language to communicate with others.

\subsubsection{Language lack of Pride}

Language lack of pride is where the people of certain language do not encourage themselves to spread and do not use the language as a symbol of identity and symbol of unity. Language lack of pride means that peoples are able to use another language to communicate with other because the reason that they do not feel proud of having the language. The assessment of other people is the important consideration that influences them for being less to use their own language.

\subsubsection{Unawareness of the Norms}


Unawareness of the norms is where the people of a certain language do not encourage themselves to use the language accurately. This is considered as a dominant factor to influences the action of language use. Unawareness of the norms towards the language means that people do not tend to use the language politely, carefully, and correctly.

\subsection{Factors Influencing Language Attitude}

According to Jendra (2010) there are several factors may influence the language attitudes:

\subsubsection{The Prestige and Power of the Language}

In many countries around the world an enthusiasm to learning English is not uncommon. Some people assume that learning foreign language (English, for example) will correlate to the declining the national loyalty of the learners. However, scholars have learned that the enthusiasm on learning a foreign language is not always correlated with a negative attitude towards the national and cultural feeling of the learners. A research on Japanese children studying English for example, proved that although the learners showed great attraction towards the Western culture as well as the language being studied, they kept holding a strong Japanese identity and a language loyalty. But since the numbers of English users around the world is so large, speakers of other languages see the situation as a pressure from the dominant group (English supporters). Thus, government of a country may consider it necessary to release some regulations in order to protect the language of its people from the English domination. This situation can be found in French as described in the following line.

\subsubsection{Historical Background of Nations}

Some Middle East people may not want to study English because they learn from their history that western people were colonialist. The view is possibly strengthened with some complicated contemporary disputes between the Western and Arabic (Muslim) cultures. Being overshowed with the misery caused by the atomic bombs dropped in their country in the past, some Japanese people today may not want to think of English as an important global vernacular that need to be learned. Thus, both the Middle East people and the Japanese hold a negative attitude towards English as an international tongue because of some historical background. The same attitude might be found among some Indonesians when they think it wrong to learn Dutch or Japanese because the languages are associated with the colonialism upon their country in the past.

\subsubsection{The Social and Traditional Factors}

In the society where a diglossic situation is found the higher variety of the language is normally considered as a better form than the lower one. In the society with a traditional polyglossia, a negative attitude may be demonstrated towards the use of language associated with a higher class, especially if it is perceived as instrumental for controlling or downgrading the other people. Some Balinese for example, may reject to use the higher variety of their tongue when talking to the people who are traditionally 'higher' especially when the people addressed in that variety respond in lower variety to them. However, if such a traditional diglossic or polyglossic situation is fading, positive reaction towards the system may come up. Thus, in order to maintain the tradition the society believe it to be necessary to learn and use the higher as well as the lower variety of the language.

\subsubsection{The Language Internal System}

People often show positive attitude towards learning a language because the grammar, pronunciation, and vocabulary are relatively easy. As the gender-based nominal systems of the language is difficult to learn English, instead of French and German. A negative attitude might be also found towards learning Chinese with its complex total pronunciation and orthographic system. An internal diglossic or polyglossic situation may also matter.

Thus although Javanese has more speakers, it was not chosen to be a national language of Indonesia, for it classifies higher (kromo inggil), middle (kromo), and lower variety (ngoko) that is not easy to learn to use by speakers of other languages in general.

\section{Methodology}

This study was conducted in descriptive qualitative research design with case study in order to describe the language attitude. According to Bogdan and Biklen (1982) qualitative research is as direct source of the data and the researcher is the key instrument, qualitative means to find out how a theory works in different phenomenon whose data collected are in the form of words rather than number. And qualitative research has the natural setting as the direct source. It means qualitative research is study things in their natural settings, attempting to make sense or to interpret phenomena in terms of the meaning people bring to them. Bogdan and Biklen (1992) state 
that case study is detailed examination of one setting or a single subject, a single depository of document or one particular event. This design was chosen because this research conducted for one case of language in a certain community.

The data of this research are the dialogue between seller and buyers in Simlaingkar traditional market and also interview between the researcher and sellers. Simalingkar traditional market is one of the famous traditional market in Medan which is located in the residential area of Simalingkar, Padang Bulan. People who live in Padang Bulan area are almost entirely go to this market to fulfill their daily needs. This traditional market provides the basic needs of everyday for the society around this area. The traders in this market consist of various tribal traders, but Bataknese and Karonese traders are traders who make up the majority in this market. The number of both is almost the same between Bataknese and the Karonese traders. In addition to Bataknese and Karonese traders, around $10 \%$ are traders of the other tribes such as Javanese, Niasnese, Mandailingnese traders, and so on. Furthermore, the society who live in the region of Simalingkar also consist of Bataknese and Karonese as a majority tribes in this region. Besides the traders who are Karonese and Bataknese who become the majority in this traditional market, the buyers who come and shop to this market are also Karonese as the majority who live in Simalingkar.

\section{Findings and Discussions}

\subsection{Findings}

Based on the data analysis there are positive and negative attitudes of traders in Simalingkar traditional market towards Karonese Language. There are 12 traders consists of 10 male traders and 2 female traders (67\%) of respondents showed positive attitudes towards Karonese Language. They said that they are responsible to use Karonese Language since it is their personal identity. There is nobody using Karonese Language unless themselves. While the researcher found 6 female traders (33\%) of respondents showed negative attitudes. They usually use Indonesian Language in their daily life activities because their husbands are not Karonese, so they do not understand Karonese Language. This means that traders in Simalingkar traditional market showed dominant positive attitudes towards Karonese Language. Based on the questionnaires and interview result, the researcher found that the respondents dominantly showed characteristics of language attitudes which indicate positive attitudes. They are language loyalty, language pride and awarness of norms.

\subsection{Disussions}

Based on the findings, the reseacher found that all the male traders in Simalingkar traditional market have positive attitudes towards Karonese Language because they consider that using Karonese Language is important because it is their identity, they are proud of using Karonese Language and are also aware of Karonese Language norms. They said that it is their responsibility to keep using Karonese Language as they belong to it. So, they always use Karonese Language in their daily life activities. They also feel accustomed to using Karonese Language with the fellow speakers of Karo Language even with the buyers who are not Karonese. But, if there is no response from the buyers, which means that they do not understand Karonese Language, the traders switch the language into Indonesian Language. On the other hand, although female traders realized that Karo Language is their idenity, they showed negative attitudes towards Karo Language because they consider that it is not important to use Karo Language. They tend to use Bahasa Indonesia or another languages in their daily life activities because their husbands come from another tribes so they are not loyal to use Karo Language. This phenomenon strengthened the theory of Garvin and Mathiot (1968) who stated that people who had positive attitudes maintain their language viability from the adverse impact of foreign language, make the language as a symbol of personal identity or as their group identity, and also encourage to use the language carefully, correctly, politely. Furthermore, the findings of this research are the same as the findings of a research conducted by Surbakti (2017). The difference is the subjects of this study are traders in Simalingkar traditional market while Surbakti (2017) took University students of Karonese in UMSU Medan as the subjects. Therefore, in this research, the reason why female respondents showed negative attitudes is because their husbands are not Karonese, so they tend to use Bahasa Indonesia in their daily life activities since their husbands do not understand Karonese Language. While in Surbakti (2017) female respondents showed negative attitudes because their friends in college and boardinghouse are not only Karonese, so they use Indonesian Language to apperciate their friends who are not Karonese.

\section{Conclussions}

Traders in Simalingkar Traditional market showed positive attitudes towards Karonese Language. There are 12 $(67 \%)$ of respondents showed positive attitudes while there are $6(33 \%)$ of respondents showed negative attitudes. There are 10 male and 2 female traders showed positive attitudes towards Karonese Language because they 
consider that they are responsible to use Karonese Language, they are proud to use Karonese Languageand are aware of Karonese Language norms. While 6 female traders showed negative attitudes towards Karonese Language because their husbands do not understand Karonese Language since they are not Karonese. So they use Indonesian Language in their daily life activities.

\section{References}

Baker, C. (1992). Attitude and Language. Key Issues in Bilingualism and Bilingual Education. Clevedon: Multilingual Matters. https://doi.org/10.2307/416953

Bogdan, R. C., \& Biklen, S. K. (1992). Qualitative Research foe Education: An Introduction to Theory and Methods (2nd Ed). Sydney: Allyn and Bacon.

Chalak, A., \& Kassian, Z. (2010). Motivation and Attitudes of Iranian Undergraduate EFL students Towards Learning English. GEMA Online Journal of Language Studies, 10(2), 37-56.

Crystal, D. (2000). Language Death. Cambridge: Cambridge University Press. https://doi.org/10.1017/CBO9781139106856

Fasold, W. R. (1984). The Sociolinguistics of Society: Introduction to Sociolinguistics. Padstow, Cronwall, Great Britian.

Fishbein, M., \& Ajzen, I. (1974). Attitudes Toward objects as Predictors of Single and Multiple Behavioral Criteria. Psychological Review, 81, 59-74. https://doi.org/10.1037/h0020074

Fishbein, M., \& Ajzen, I. (1975). Belief Attitude, Intention and Behavior: An Introduction to Theory and Research. London. UK: Addison-Wesley.

Garvin, P. L., \& Mathiot, M. (1968). The Urbanization of Guarani Language: Problem in Language and Culture. In J.A. Fishman, (Ed.) Reading in Text Sociology of Language. Mounton: Paris- The Hague. https://doi.org/10.1515/9783110805376.365

Jendra, I. I. (2010). Sociolinguistics: The study of societies' languages.Yogyakarta: Graha Ilmu

Holmes, J. (2001). An Introduction to Sociolinguistics. New York: Longman.

Norton, B. (2000). Identity and Language Learning: Gender, Ethnicity and Educational Change. Harlow, UK: Pearson Education/Longman.

\section{Copyrights}

Copyright for this article is retained by the author(s), with first publication rights granted to the journal.

This is an open-access article distributed under the terms and conditions of the Creative Commons Attribution license (http://creativecommons.org/licenses/by/4.0/). 